$$
\text { 폐농양의 임상적 고찰 }
$$

$$
\begin{gathered}
\text { 연세대학교 의과대학 내과학교실 } \\
\text { 김기호 - 정우제 · 김경년 - 정재윤 - 김성규 - 이원영 }
\end{gathered}
$$

$=$ Abstract $=$

\title{
A Clinical Observation on Lung Abscess
}

Ki Ho Kim, M. D., Woo Jae Chung, M. D., Kyung Nyun Kim, M. D., Sung Kyu Kim, M. D., and Won Young Lee, M. D.

Dept. of Internal Medicine, Yonsei University, College of Medicine

A clinical study was performed on 102 cases of lung abscess admitted in Severance Hospital during last 7 years of period from 1970 to 1976 .

The results are summerized as follows:

1. The ratio of male to female was 4.1:1. Most patients were in the age group between the fourth and sixth decades $(70 \%)$.

2. The most common predisposing tactor of lung abscess was pneumonia (24.5\%). Aspiration (19.6\%), bronchial obstruction (5.9\%), metastatic lung abscess (1\%) were found in the order of frequency. The etiologic predisposing factor was uncertain in $49 \%$ of all cases.

3. The common clinical manifestations were cough, purulent sputum, fever and chill, chest pain, hemoptysis, dyspnea and anorexia in the order of frequency.

4. Bacteriologic studies of the sputum with culture were revealed alpha-streptococcus $(79.4 \%)$, aerobacter (19.5\%), pseudomonas(10.8\%), staphylococcus $(5.4 \%)$, beta-streptococcus $(5.4 \%)$ in the order of frequency. organisms more than one were found in 42 cases (56.4\%).

5. The most frequent location of lung abscess was right lower lobe (30\%), right upper lobe $(28 \%)$, left lower lobe $(20 \%)$, left upper lobe $(8 \%)$ were common site in the order of frequency.

6. Eighty-eight out of 102 cases (86.3\%) were treated with medical treatment. $14 \mathrm{c}$ ases $(13.7 \%)$ required surgical therapy.

7. The mortality rate of 102 cases with lung abscess was $8.8 \%$ (9cases).

8. The diagnostic value of sputum culture was limited. prospective study through transtracheal aspiration, bronchoscopy, transthoracic lung puncture etc. are recommanded for better pathogenic identification of lung abscess.

본 논문의 요지는 제 45 차 추계결핵학술대희 석상에서 발표하였음 


\section{서 론}

폐농ㅇ양은 항생제의 개발이 전에는 매우 높은 사 망률과 합병증을 유발하던 질 환이었으나 항생 제의 개 발로비교적 용이하게 내과적으로 치유되기 때문에 그 치료방법에 있어서도 많은 변화를 가져왔다 하겠 다. 또한 기본검사 이외에 transtracheal aspiration, fiberoptic bronchoscopy등에 의한 원인균의 배양 은 특히 혐기성균의 중요성을 강조하게 되었다. 최 근의 우리나라의 폐농양의 빈도및 원인균, 치료경 향등을 고찰하는 것은 의의있는 일로 생각된다. 이 에 저자등은 1970 년부터 1976년까지 7년간 연세대 학교 부속 세브랸스병원에 입원한 환자중 흉부 엑 소-선소견으로 폐농양으로의 진단을 받은 102 명을 대상으로 그 임상상을 관찰하여 이에 보고하는 바 이 다.

\section{관찰대상 및 방법}

1970년부터 1976년까지 연세대학교 의과대학 부 속 세느란스병원에 입 원하였던 폐농양환자중 훙부 엑스-선소견으로 폐농양으로 진단받은 102 예를 대 상으로 하였다.

\section{관찰 결과}

\section{1) 년도별 빈도}

본원에 입원하였던 폐농양환자의 년도별 빈도를 보면 1970 년도에 입원 환자 10,000 명당 11.2 예, 17 71 년에 12.3 예였으며 1982 년에 6.3예, 1973년 6.8 예, 1974년 6.7예, 1975년 9.9예, 1976년 11.3 예 였다. (제 1표)

\section{2) 성별 및 연령}

폐농양 환자 192 예중 남자 82 예, 여자 20 예로남 녀비는 4.1:1로 남자에 많았으며 연령별로는 40 대 가 26 예로 가장 많았고 50 대가 25 예, 30 대가 20 예의 순이었으며 전에의 $70 \%$ 가 30 대와 50 대 사이 였다. (제2표)
Table 1. Annual Occurence of Lung Abscess

\begin{tabular}{|c|c|c|}
\hline \multicolumn{3}{|c|}{$1970 \cdots \cdots \cdots 1976$} \\
\hline Year & No. of Case & Cases $/ 10,000$ Admissions \\
\hline 1970 & 19 & 11.2 \\
\hline 1971 & 21 & 12.3 \\
\hline 1972 & 10 & 6.3 \\
\hline 1973 & 11 & 6.8 \\
\hline 1974 & 11 & 6.7 \\
\hline 1975 & 14 & 9.9 \\
\hline 1976 & 16 & 11.3 \\
\hline
\end{tabular}

Table 2. Age and Sex Distribution of 102

\begin{tabular}{rccr}
\multicolumn{5}{c}{ Patients with Lung Abscess } \\
\hline \hline Age & Male & Female & Total \\
\hline-10 & 3 & 1 & 4 \\
$10-20$ & 3 & 0 & 3 \\
$21-30$ & 8 & 6 & 14 \\
$31-40$ & 12 & 8 & 20 \\
$41-50$ & 23 & 3 & 26 \\
$51-60$ & 23 & 2 & 25 \\
$60-$ & 10 & 0 & 10 \\
Total & 82 & 20 & 162 \\
\hline
\end{tabular}

Table 3. Predisposing Factors in Lung Abscesses

\begin{tabular}{lcc}
\hline Predisposing factors & No. & Percentage \\
\hline Aspiration & 20 & 20 \\
Pneumonia & 25 & 25 \\
Obstruction & 6 & 6 \\
Metastatic $\quad$ lung abscess & 1 & 1 \\
Unknown & 50 & 49 \\
\hline
\end{tabular}


3) 원 인

원인별로는 급성 페엄이 25 예 (25\%로 가장 많 았三, 훕인병력이 20 예 $(20 \%)$, 기관지 폐쇄 6 예 $(6 \%)$, 전기성 폐농양 1 예 $(1 \%)$ 의 순이였으머 병 력이 불확실한 예가 50 예 ( $49 \%$ ) 였다. (제 3 표)

\section{4) 증 상}

제 4 포와 같이 기침을 호소하 예가 $77 \%$ 로 가장 많았고 농담객( purulent sputum)이 65\%, 발열및 오한이 $40 \%$, 항통이 $24 \%$ 의 순이었으며 그외 각 혈 호흡곤란 체중감소를 호소했다.

\section{5) 원인균}

객담의 세균배양으로 균이 확인된 예는 92 예 ( 90 $12 \%)$ 로 이중 $\alpha$-streptococcus 가 73 예 ( $79.4 \%$ ) 로 가장 믾았고 aerobacta 18예(19.5\%), pseudomonas 16혜 ( $10.8 \%$ ), staphyeococcus 5 예 ( $5.4 \%)$ $\beta$-stroptoccus 5 예 $(5.4 \%)$ 등이였으며 5 예의 경 우 transtracheol aspiration 을 시행하였는데 이들 의 혐기성 배양에서 peptostreptococcus 4 예, fusobacterium 3 예 가 분리되었다. 92 예중 42 예 (56.4 $\%)$ 에서 2 가지 이상의 균이 분리된 혼합감염 이었 다. (제 5 표)

\section{6) 방사선학적 부위}

훙부 엑스선및 기관지경에 의하여 확인된 폐농 양의 위치는 제 6 표와 같이 우폐에 $64 \%$ 좌 폐에 $36 \%$ 로 우폐에 많았으며 엽상별로는 우하엽이 31 예 $(30.4 \%)$ 로 가장 많았고 우상엽 29 예 $(68.4 \%)$. 좌하엽 20 예(19.6\%), 좌상엽 8 예 $(7.8 \%)$, 우중엽 6 예 $(5.9 \%)$ 다발성 폐농양 4 예 $(3.8 \%)$ 의 순이였고 불명확한 예가 4 예 $(3.9 \%)$ 이었다.

\section{7) 치료방법}

제 7 표와 같이 102 예중 내과적 치료를 받은 예 가 88 예 $(86 \%)$, 외 과적치료를 받은 예가 14 예 ( 14 $\%)$ 였다.

\section{8) 사망률 및 합병증}

폐농양 환자 102 예중 9 명 $(8.8 \%)$ 이 사망하였으 며 그중 폐결핵을 수반하였던 예가 4 예, 패혈증 3
Table 4. Frequency of Symptoms in 102 Patients with Lung Abscess

\begin{tabular}{lcc}
\hline \hline Symptoms & No. & $\%$ \\
\hline Cough & 79 & 77 \\
Purulent sputum & 66 & 65 \\
Fever and chill & 41 & 40 \\
Chest pain & 24 & 24 \\
Hemoptysis & 16 & 16 \\
Dyspnea & 15 & 15 \\
Anorexia & 4 & 4 \\
Night sweat & 1 & 1 \\
\hline
\end{tabular}

Table 5. Microorganisms Found on Culture of Sputum

\begin{tabular}{lr}
\hline \hline \multicolumn{1}{c}{ Organism } & No. of cas \\
Alpha-steptococcus & 73 \\
Aerobacter & 18 \\
Pseudomonas & 10 \\
Staphylococcus & 5 \\
Beta-streptococcus & 5 \\
Gamma-streptococcus & 4 \\
Peptostreptococcus & 4 \\
S. pneumoniae & 3 \\
E. Coli & 3 \\
Diphtheroid & 3 \\
Fusobacterium & 3 \\
H. influenza & 2 \\
Enterococcus & 2 \\
Herellea & 2 \\
Others & 8
\end{tabular}

* Mixed infection:42 cases

* Unknown:10cases 
예, 폐암 1 예, 농홍 1 예, 기관지천식 1 예이었다(게 8표).

9) 치유기간

내과석치료를 받은 환자중 비교적 추적관찰이잘 되었던 27 예의 임상결과를 보면 제 1 도와 같이 체 온은 3 주이내을 대부분이 정상으로 되었으며 공 동은 4 6주에서 대부분이 없어졌다. 공동부위의 침윤은 대개 8 주에서 소실되었으나 어떤 예에서는 18 주까지 지속하는 예도 있었다.

\section{고 안}

폐농양이란 폐실질을 파괴하여 황농물과 공기를 포함하는 동공을 가지는 화농성 폐감염을 말한다.'

폐농양의 원인으로는 감염물질의 흡인이 가장 많 다. 이를 흡인폐농양의 경우 대개 의식소실의 병 력을 흔히 볼 수 있는데 그중에서도 과도한 음주 혹은 만성 알콜중독자가 많다. 그외, 원인으로는 발 작중, 마취, 구강및 인후부수술, 당뇨성 혼수, 대량의 진정제복용, 혹은 여러가지 신경질환등이 있다. 폐 농양을 가진 많은 환자에서 구강질환을 가지고 있 는데 이들의 치아와 치주주위에는 많은 감염원이 추적되어 있다. 이가 없는 사람에서는 폐농양이 희
Table 6. Radiographic Location of Lung Abscess

\begin{tabular}{lrr}
\hline Locations & No. & $\%$ \\
\hline Right lung & 29 & 28 \\
Upper lobe & 6 & 6 \\
Middle lobe & 31 & 30 \\
Lower lobe & & \\
Left lung & 8 & 8 \\
Upper lobe & 20 & 20 \\
Lower lobe & 4 & 4 \\
Multiple & 4 & 4 \\
Undetermined &
\end{tabular}

Table 7. Treatment in 102 Patients with Lung

\begin{tabular}{lc}
\multicolumn{2}{c}{ Abscess } \\
\hline Treatment & No. \\
\hline Medical & 88 \\
Surgical & 14 \\
\hline
\end{tabular}

Table 8. Associated Diseases in 9 Death in 102 Patients

\begin{tabular}{lc}
\hline \hline Diseases & No. \\
\hline Pulmonary tbc. & 4 \\
Sepsis & 3 \\
Lung cancer & 1 \\
Empyema & 1 \\
Asthma & 1 \\
\hline
\end{tabular}

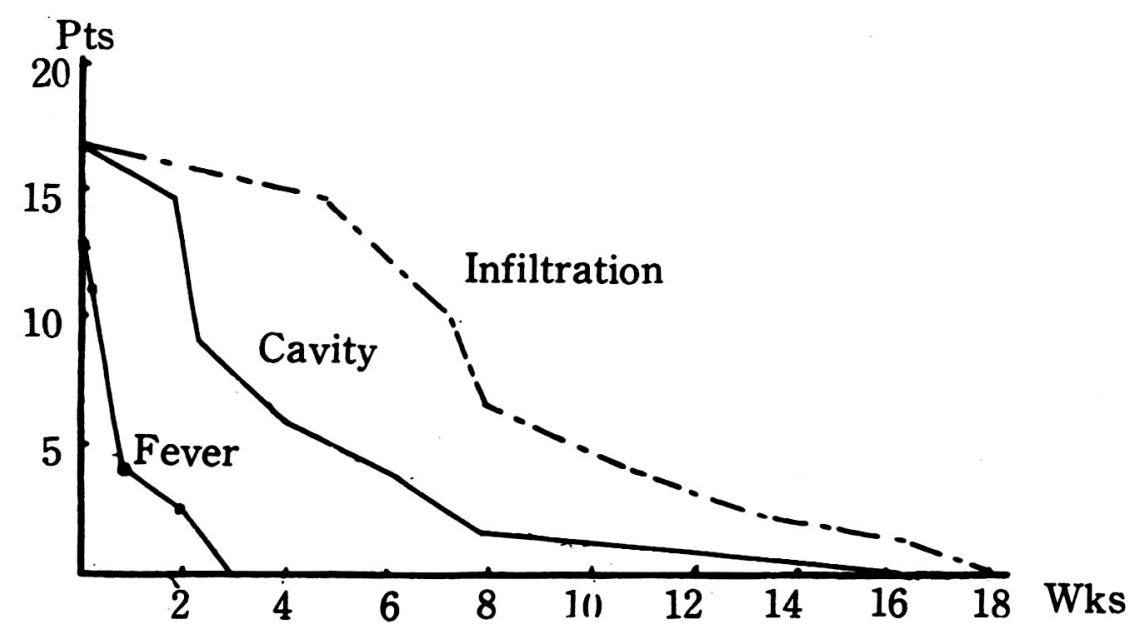

Fig. 1 Response to Antimicrobial Therapy for Lung Abscess 
귀하다는 것이 잘 알려진 일이다. 과거에는 구강 이나 편도선 수술중 감염물질(infected material) 을 흡인하는 것이 폐농양의 혼한 원인이었으나 최 근 마취술의 발달로 비교적 드물다. 상기도부나 식 도를 침범하는 악성종양의 경우 흡인성 폐농양이 많다. 폐염 특히 staphylococcus aureus 나 klebsiella에 의한 폐염이 종종 폐농양을 형성한다. 그러 나 일차성 폐염균 폐염 (pneumococcal pneumcoaia) 은 폐농양을 잘 형성하지 않는다. 정상방어기전을 억제하는 약물 즉 부신피질홀몬제나 항암제를 사 용한 경우 흔히 폐염이 폐농양으로 이행된다. 사실 많은 병원에서 암의 말기환자에서 많은 폐농양을 보이고 있다. 그 다음으로는 기관지폐쇄가 혼히 폐 농양을 일으키는데 이러한 기관지폐쇄는 bronchogenic 폐암이 혼한 원인이지만 이물질이나 임파선 이 기관지를 눌러서 일으키기도 한다. 패혈성 emboli에 의한 전이성 폐농양은 주로 세균성 심내막 염 혹은 pelvic thrombophlebitis에 기인하는데 간 혹 패혈증의 합병증으로도 일어난다. 원인에 따른 일반적인 폐농양의 분류는 제 9 표와 같다. 일반 적으로 흡인성폐농양의 $70 \%$ 는 알콜성 혼수에 기 인된다. 3) 본조사의 경우도흡인의 대부분은 만취에 의한 의식소실이 대부분의 원인이었지만 전예중 20 $\%$ 에서만이 흡인의 병력을 볼 수 있었으며 그외 2 차적인 폐농양으로 폐염이 $25 \%$, 이 물질에 의한 기관지폐쇄가 $6 \%$ 였다. 원인이 확실하지 않았던 예 는 $49 \%$ 였는데 이들의 병력을 자세히 찾아 보았 으면 아마도 흡인병력이 이들중 많이 포함되어 있 으리라 생각된다. 이등 ${ }^{4)}$ 은 약 $41 \%$ 에서 金등은 ${ }^{5)}$ $31 \%$, 朴 ${ }^{6)}$ 등은 $13 \%$ 에서 원인불명이라고 하였다. 폐농양은 주로 남자에 많으며 주로 환동적인 년령 에 많다. 남녀비는 약 $4: 1$ 로 보고되고 있는데 ${ }^{6,7}$, 8, 9, 10) 본조사의 경우도 $4.1: 1$ 로 다른 보고와 비 슷했다.

폐농양의 형성기전 및 호발부위를 보면 감염된 물질이 기관지로 흡입되여 폐의 dependent portion 의 작은 기관지에 막히게 되며 막힌 기관지 주위 조직에 폐염이 형성되며 괴사 및 액화의 결과로 동공이 형성되며 괴사결과 형성된 화농이 기관지 를 통하여 흘러나오므로 심한 악취가 나게된다. 폐실질이 괴사되기위하여는 폐의 결체조직, elastic framework 가 파괴되어야 하는데 이의 정확한 기
TABLE 9

Classification of lung abscess according to cause

$I$ Nerrotizing infections

$A$ Pyogenic bacteria

Staphylococcus aureus,

Klebsiella, group A streptococcus,

Bacteroides,

Fusobacterium,

Anderobic and microaerophilic cocci and streptococci, other anaerobes, Nocardia

$B$ Mycobacteria

Mycobactorium tuberculosis,

M. kansasii,

$M$. intracellularis

$C$ Fungi

Histoplasma,

Coccidioides

$D$ Parasites

Amebas,

Lung flukes

II Cavitary infarction

$A$ Bland embolism

$B$ Septic embolism

various anaerobes,

Staphylococcus,

Candida

$C$ Vasculitis

Wegener's granulomatosis, periar teritis

IIICavitary malignancy

$A$ Primary bronchogenic carcinoma

$B$ Metastatic malignancies very uncommon

\section{IVOther}

$A$ Infected cysts

$B$ Necrotic conglomerate lesions Silicosis,

Coal miner's pneumoconiosis 
전은 확실하지 않으나 폐염주위의 소혈관의 혈전이 폐실칠의 ischemia 를 형성하고 기관지폐쇄를 일으 킨 감염물속의 세균에 의해 분비되는 단백분해효소 (proteolytic enzyme)의 결과로 알려지고 있다. 2 7. 8, 11, 12) 폐농양의 호발부위는 흔히 supine위치 에서 흡인이 일어 나기때문에 상엽의 posterior segment, 하엽의 superior segment 가 가장 혼히 침범된다. ${ }^{10)}$ Bernhard $^{2)}$ 의 6 개의 폐농양문헌 ${ }^{7,8}$ 9, 13, 14, 15) 을 종합한 부위별 빈도를 보면 총 501 예중우상엽 $35.2 \%$, 우중엽 $8.4 \%$, 우하엽 $25.6 \%$ 좌상엽 $17.3 \%$, 좌하엽 $13.5 \%$ 로 되어 있는데 본 조사의 경우도 우하엽 $30 \%$, 우상엽 $28 \%$ 로 우폐 에 많아서 상기보고와 비슷하다 하겠으나 본 조사 의 경우는 우하엽이 우상엽보다 약간 많았다.

폐농양의 일반증세는 대개 발열, 발한, 피곤, 식 욕부진, 체중감소등으로 시작하여 수일후 혹은 수 주일 기침을 하여 많은 가래가 나오기 시작한다. 가래에서 심한 악취가 나며 약 $40 \%$ 에서는 각혈 을 하게 되고 형통, 호흡곤린을 느끼기도 한다.

이학적소견상 많은 예에서 치주질환을 가지고 있 으며 청진소견상 moist rales을 들울 수 있으며 타 진상 濁音을 종종 발견할 수 있다. 약 $\frac{1}{4}$ 정도에서 는 clubbing finger를 볼 수 있다. 본관찰듸 경 우도 기침, 농객담, 발열, 오한이 많았으며 각혈
이 $16 \%$ 로 타보고 ${ }^{2,16)}$ 보다 낮았으며 朴등하은 59.2 $\%$, 金등 ${ }^{5}$ 은 $32.9 \%$ 에서 각혈을 보고하고 있다. 폐농양의 원인균은 주로 홉인시 폐에 도달한 구 강내 resident flora이다. 이러한 점에서 폐농약과 치주질환 흑은 불결한 구강위상과는 밀접한 관계가 있다. 험기성세균 특히 bacteriodes, fusobacterium 과 streprococci 및 그외 구균들이 구강질환의 중 요한 세균들이며 이들이 흡인시 폐에 들어 갈때 폐농양을 일으킨다. 혐기성세균에 의한 폐농양의 약 $80 \%$ 에서 홉인의 병력이 있거나 구강의 질환 을 발견할 수 있다. ${ }^{17,18,20)}$ 그러나 이제까지 이러 한 혐기성 세균들이 원인균으로 잘 알려지지 않은 이유는 이러한 혐기성세균의 배양이 매우힘들며 또 한 일반객담배양으로는 구강내의 normal flora 와 구분할 수 없어 원인균으로 가정하기 힘든점이 있 기때문이었다. 항생제를 투여한 경우 혹은 병원에 입원하여 병원균에 감염된 경우, 혐기성세균이외 에 staplylococcus aureus, klebsiella 등이 종종 발 견된다. 특히 만성알코홀중 독자, 당호.병 혹은 다 른 숙주방어기전 (host defence) 의 장애를 가진 환 자에서 특히 staphylococcus aureus, klebsiella 의 감염이 흔히 일어난다. 본 조사의 경우 대부분이 입원당시 객담배양을 하였으며 혐기성 세균배양 은 항상 하지는 않았다. 객담배양검사 결과를 보

Table 10. Frequency of Organisms recovered in 104 Patients.

\begin{tabular}{lcc}
\hline Organism & No. of Cases & Percentage \\
\hline Alpha-hemolytic streptococcus & 74 & 71 \\
Beta-hemolytic streptococcus & 26 & 25 \\
Staphylococcus aureus & 14 & 13.5 \\
Nonhemolytic streptococcus & 14 & 13.5 \\
E. coli & 9 & 8.1 \\
Hemophilus influenzae & 4 & 3.8 \\
Diplococcus pneumoniae & 3 & 2.9 \\
Fungi (not otherwise specified) & 3 & 2.9 \\
Pseudomonas aeruginosa & 2 & 2 \\
\hline
\end{tabular}

* 1 organism found in 32 patients $(31 \%)$ 
if $\alpha$-strceptococcus가 73 예로. 제일 많았고 aerohacter 18예, psendononas 10예, staphylococcus 5 예, $\beta$-streptococcus 5 예의 순이였으며 42예 (56.4 $\%$ )에서 2 개이상의 혼합감염의 양상을 보였는데 Schweppe $(1961)^{15)}$ 의 104 예의 객담배양검사를 보 면 제 10 표와 같이 $\alpha$-hemolytic streptococcus 가 $71 \%$ 라장 많고 $\beta$-hemolytic streptococcus 가 $25 \%$, staphylococcus aereus 가 $13.5 \%$, non hemolytic streptococcus $13.5 \%$, E. coli $8.1 \%$ 의 순 이였으며 $31 \%$ 에서 2 가지 이상의 혼합감염이었으 며 다른 보고를 $\left.{ }^{3}, 16,17,18\right)$ 로 비슷한 소견을 보고 하고 있는데 이들은 모두 객담의 초기배양(aerobic culture)을 주로한 보고들이다. 이들과 본관찰과를 비교하면 throat normai flora 의 배양은 비슷하지 만 staphylococcus aereus, E. coli 등의 발견율이 비교적 낮다 하겠다. 그러나 transtracheal aspiration울 항! 혐기성 배양을 철저하 한 몇몇보 고는 ${ }^{19,20)}$ 대부분이 fusobacterium nucleatum, bacteroides melaninogenicus, peptostreptococcus, peptococcus등이 대부분이다. 본관찰의 겅우 5예 에서 transtracheal aspiration 을 시행하여 peptostreptococcus 4예, fusobacterium 3예가 관찰되었 다. 일 반적으로 객담세균배양으로는 정확한 원인균 을 확인하기가 힘들며 혐기성배양의 경우에도 그 진단적 가치가 낫기 때문에 최근에는 trans-tracheal aspiration, fiberoptic bronchoscopy, transthoracic lung puncture 등을 통한 검사물이나 혹은 empyema fluid을 배양함으로 원인균을 확인하는것 이 권장된다. 물론 혐기성배양에는 검사물의 채취 족시 무산소상태의 튜브 혹은 채집병에 곧 옮겨 심 으며 곧장 배양실에 보내야하는 기술적인 면에도 세심한 주의를 필요로 한다.

폐농양의 치료는 크게 내과적치료와 외과적치료 로 대별할수 있다. 내과적 치료의 경우 이제까지 그 원인균을 분리하기가 힘들기때문에 경험적 치 료일수 밖에 없었다. 페농양 환자 치료에 있어 제 일 중요한 것은 호기성 화농균 특히 staphylococcus, klebsiella 그리고 결핵성 동공을 배제하는 것 이다. 이는 대개 병력이나 이학적소견, 홍부엑스 선소견, 자세한 객담검사의 gram 염색및 $\mathrm{AFB}$ 염 색으로 구분할 수 있다. 원인균이 발견되면 이에 대한 적절한 항생제의 투여가 제일 중요하다. 그
러나 임상소견상 홉인의 가능성이 많고 객담 $\mathrm{gram}$ 염색에서 '혐기성세균의 소견을 보이면 항생제 는 이 혐기성세균에 효과적인 약제를 수택하여야 한 다. 특히 혐기성세균에는 penicillin이 가장 좋은약 이며 일반적으로 대량(대개 5 백만 1천만 unit) 을 정 맥으로 사용한다. 혼합감염의 경우 penicillin 에 저항균이 있는 경우에도 penicillin 단독으로 대개 효과적이다. 실험실적 내성검사에서 penicillın 에 저항력있는 bacteriodes fragilis 가 약 $25 \%$ 에서발 견된다고 하나 이의 원인균으로서의 중요성은 아 직 확실하지 않다. 한편 환자상태가 매우 나쁘고 penicillin 에 반응이 없으면 clindamycin 혹은 chloramphenicol이 대부분의 혐기성세균에 효과 가 좋기때문에 이를 첨가하거나 penicillin 알러지 반응환자에서는 penicillin 대신 이들을 대치할 수 있다. ${ }^{20,21)}$ 항생제의 투여기간은 적어도 $4 \sim 6$ 주의 계속적인 투여가 필요하다. 이는 혐기성세균의 부 분적인 저항력때문에 또는 너무 일찍 항생제를 중 단하면 재발이 잘 되기때문이다. 항생제의 변경은 활실한 임상적, 방사선학적, 재발의 소견에 의하 여 행해져야 하며 단순히 객담배양검사상의 균의 변화는 별 의의를 갖지 못한다. 대개 심한 임상 toxic증상이 없어지고 방사선학상 폐염의 소견이 없어지며 공동크기가 감소하고 공동속의 fhuid level 이 없어지면 penicillin을 근육 혹은 경구투여하며 공동주위의 침원이 없어지면 항동제를 중단할 수 있다. 폐농양의 치효중 적당한 항생제를 선택하여 투여하는 것이 제일 중요하지만 그외 각담을 묽 게 한다든지, 제거를 돕기위한 보조요법으로 postural drainage 및 물리요법이 중요하다. 최근 매 우 유연한 fiberoptic bronchoscopty 가 개발되면서 그 사용이 간편하고 조작이 용이하며 환있에게 심 한 부담을 주지 않고 또한 이를 이용한 천자, bronchial washing 의 진단적, 치료적 가치가 매우 높기때문에 회근에는 대부분의 폐농양환자에서 시 행하고 있다. 특히 종양이나 이물이 폐농양의 원 인으로 의심스러울때에는 이물의 제거및 세포검사 를 위해 필수적이다. ${ }^{20)}$

최근 항생제의 발달로 대부분의 폐농양환자가 내과적 치료로 쾌유되고 있으며 외과적 치료는 특 별한 경우에 한한다. 많은 보고들이 16, 19, 19, 22, 23) 약 $80 \%$ 에서 내과적 치료로 완쾌를 보고하고 있 
으며 그 평규사망률을 Sehweppe ${ }^{15}$ 는 $8.7 \%$, Chidi

17 는 $19.7 \%$ 로 보고하고 있다. 본 관찰의 경우 102 예중 88 예 (86\%)에서 내과적치료를 받았으며 10 예 $(9.8 \%)$ 에서 외과적 치료를 받았다. 그중 사망자 가 9 예 $(8.8 \%)$ 이였는데 사망자의 대부분은 내과적 치료로 실패했고 수술을 받기 힘든 상태였던 환자 로써 4예에서는 폐결핵을 합병중으로 가지고 있 었으며 3 예에서는 패혈중을 그리고 폐암, 기관지 천식이 1예씩 있었이. 1예는 농훙으로 chest tube 를 꼽았으나 사망하였다. 외과적 치료를 받았던 14 예중 13예가 모두 건강이 희복되여 퇴원하였는 데 이는 역시 항생제가 발달하였어도 적철한 외 과적 적웅중이 되면 수술이 매우 효과적이라는 것을 의미한다. 물론 최근 항생제의 발달로 폐농 양의 치료가 대부분이 내과적 치료이며 수술을 받 는 대부분 환자가 적극적인 내과치료에도 반응을 보이지 않아 악성종양을 의심하고 수술하거나 늑 막내로 농양이 터져서 농기홍을 형성한 응급의 경 우이기때문에 사실 수술의 적응중을 말하기란 힘 들다. 특히 항생제의 투여로 체온이 정상이고 객 담의 양이 감소하고 환자가 퇴원하기를 원하면 사 실 언제 내과적 치료를 초기하고 수술을 할 것인 가는 매우 어려운 문제이다. Chidi ${ }^{15}$ 가기술한 폐 농양수술의 적응중을 보면

1. 내과적 치료에 실패한 경우

A. 발열 흑은 toxic 중상이 적절한 항생제의 투 여에도 수일동안 계속되면 bronchoscopy를 시행 하여 천자및 drainage를 시도하며 만약drainage 가 잘 안되면 external drainage 흑은 절제수술을 환자의 상태, 연령에 따라 고려한다.

\section{B. 악성종양을 의심할때}

\section{Table 11. Indication of Surgical T'reatment}

1. The complicated problems of massive he hemoptysis.

2. Lack of response to antibiotics.

3. Presence of a cavity that is thick-walled or of large size $(6 \mathrm{~cm}$ or more).

4. When a malignant lesion is suspected.

4. When empyema develops.

6. The development of chronicity.
C. 4 6주의 항생제 투여로 임상중상이 호전되 었음에도 residual cavity 가 $2.0 \mathrm{~cm}$ 이상일때

D. 항생재 투여로 임상증상이 호전된후 재발될 때.

2. 늑막강으로 폐농양이 터셔 농가홍을 형성했 을때 등이다. 일반적인 수술 적응중을 보면 table 11 과 같다. ${ }^{21,24,25,26)}$

폐농양의 예후를 보면 1940 년대이전 $35 \%$ 이상 의 사망률과 많은 합병중을 초래하였으나 ${ }^{21,22,27}$ 1950 년이후 항생제의 발달과 외과적 수술기술의 향 상으로 그 사망률은 매우 낮으며 대부분의 경우 내 과적으로 쉽게 치료될 수 있다. 따라서 폐농양의 예후는 알코홀중독증, 습관성 약물중독중, 중추신 경질환등 그 원인적 합병질환에 주로 영향을 받는 다. 이러한 질환을 가진 사람에서 흡인이 일어나 지 않도록 조심하여 치아 혹은 치주질환의 치료및 구강위생을 청결히 함으로써 이들에게 특히 혐기 성세균에 의한 폐농양을 예방하도록함이 중요여다.

\section{결 론}

항생제의 광범운한 예방적 투여및 급성 폐염중 에 대한 효과적인 사용으로 폐농양의 발생빈도, 임상상및 그 예후에 많은 변화를 가져오고 있다. 저자등은 1970년부터 1976년까지 7년간 연세대학 교 부속 세브란스병원에 입원한 환자중 훙부 엑스 - 선 소견으로 폐농양으로 진단받은 102 명을 대 상으로 그 임상상을 관찰찰하여 다음과 같은 결과 를 얻었기에 보고하는 바이다.

1) 대상환자의 성별은 102 명중 남자82예 (80.4 $\%$, 여자 20예(19.6) 로 $4.1: 1$ 의 비율로 남자가 많았으며 년령분포를 보면 40 대가 26 예, 50 대가 25 예 30 대가 20 예의 순으로 전예의 $70 \%$ 가 30 대와 50 대 사이였다.

2). 년별분포는 입원환한 10,000 명에 대하여 1970 년 11.2, 1971년 12.3예, 1924년6.7예, 1975년 9.9 예, 1974 11.3에였다.

3) 폐농양의 유발인자를 급성패염이 25예 (24.5 $\%)$, 흡인 20예(19.6), 기관지 폐쇄 6예 (5.9\%), 전이성 폐농양 1 예(1\%)이었고 병력이 불확실한 예가 50 예로 $49,0 \%$ 이었다.

4) 객담의 세균배양으로 균이 확인된 예는 92 예 
(90.2\%) 로 이중 $a$-streptococcus 가 73 예 (79.4 $\%$, aerobacter 18예 (19.5\%), pseudomones 10예 (10.8\%), staphylococcus 및 $\beta$-streptococcus가 각 각 5 예 $(5.4 \%)$ 였으며 그외에도 $\gamma$-streptococcus, E. coli, S. pneumoniae, diphtheloid 등이 있었고 이중 42 예 $(56.4 \%)$ 가 흔합감염이었다.

5) 홍부 엑스-선및 기관지경에 의하여 확인된 폐농양의 위치는 우하엽 31예(30\%), 우상엽 29예 (28\%), 좌하엽 20예 (20\%) 좌상엽 8예(8\%), 우 중엽 6 예 $(6 \%)$, 다발성 폐농양 4 예 $(4 \%)$ 의 순이 였고 불명확한 예가 4 예 $(4 \%)$ 였다.

6) 입원당시의 중요중상은 기침, 악취를 동반한 객담, 발열및 오한, 훙통, 각혈, 호흡곤란등의 순
이였다.

7) 치료는 항생제및 내과적 보조요법으로 치료 한 예가 88 예 $(86 \%)$ 였고 외과적 처치를 받은 예 를 14 예 $(14 \%)$ 였다.

8) 사망환자는 9 예 (8.8\%) 로서 이중 폐결핵 4 예, 패혈중 3 예, 폐암 1 예, 농흥 1예, 기관지천식 1 예가 병발되어 있었다.

9) 객담배양검사의 원인균에 대한 진단적가치 는 매우 낮으며 대부분이 구강의 normal flora였 다. 정확한 원인균 규명을 위해서는 transtracheal aspiration, bronchoscopy, transthoracic lung puncture등을 통한 세균배양검사가 요구되며, 혐기 성배양을 동시에 시행토록 함도 중요하다. 


\section{References}

1. Beeson, P. B., Mc Dermott, W.: Textbook of Medicine, 14th ed.,W. B. Sounders company. Philadelphia, 1975

2. Bernhard, W. F., Malcolom, J. A., Wylie, R. H.: Lung abscess; $A$ study of 148 cases due to aspiration, Disease of the Chest 43:620, 1963

3. Perman, L. V., Lerner, E. and D'csopo, N.: Clinical classification and analysis of 97 cases of lung abscess, Amer, Rev. Resp. Dis. 99:390, 1969

4. 李復熙, 崔秉鎬, 金鍾馨, 朴宗煥, 元鎮殖：肺 膿禮場 75例의 臨床的 考察 : 大韓内科學會雜 誌 $11: 565,1968$

5. 金正吉, 尹春烈, 孔光篓, 朴洪培, 許珍得 : 肺 膿瘍의 臨床的考察, 대한 내과학희잡지 20 : 602,1977

6. 朴海珍, 朴洪培, 趙玉根, 金洪植 : 肺膿瘍患者 76 例에 封한 臨床的 觀察, 大韓内科學会雜誌 $12: 43,1969$

7. Drake, E. H., and Sonnes, F.M.: Management of lung abscess with special reference to place of antibiotics in therapy, Ann. Int.Med. 35:1218, 1951

8. Fifer. W. R., Busebye, K., Ghedister, C. and Miller, N.: Primary lung abscess, analysis of therapy and results in 55 cases, Arch. Int. Med. 107:668, 1961

9. Taber, R: E., Ehrenhaft, J. L.: Chronic lung abscess, fifteen years of change, Arch. Surg. 67:259, 1953

10. Quinn, L.H., and Meyer, O. O.:Arch. Otolaryng. 10:152, 1929, cited by Brock, R. C., In anatomy of the bronchial tree, $p .20$.

11. Brock, R. C.: Lung absess, Blackwell Scientific Publications, Oxford, 1952

12. Wolcott, M. W., Coury, O. H. and Baum, G. L.: Changing concepts in the therapy of lung abscess; $A$ twenty years survey, Dis. Chest. 40: 1,1961

13. Ban, B.: Lung abscess in India, J. Thor. Surg. 32:254, 1956

14. Bosher, L. H.: A review of surgically treated ling abscess, J. Thor. Surg. 21:370, 1951

15. Schweppe, H. I., Knowles, J. H. and Kane, L.: Lung abscess; An analysis of the Masachusetts General Hospital cases from 194.3 through 1956, New. Engl. J. Med. 256:1039, 1961

16. Bumbangh, I. F., Prior, J. A.: Lung abscess, $A$ review of forty-one cases Ann. Int. Med. 55: 223, 1961

17. Chidi, C. C., and Mendelsohn, H. J.: Lung abscess, $a$ study of the results of treatment based on 90 consecutive cases, The Journal of Thoracic and Cardiovascular Surgery 68:168, 1974

18. Bartlett, J. G., Gorbach, S. L., Tally, F. P. and Finegold, S. M.: Bacteriology and treatment of primary lung abscess, Amer. Rev. Resp. Dis. 109:510, 1974

19. Bartlett, J. G. and Finegold, S. M.:Anaerobic infections of the lung and pleural space:Amer. rev. Resp. Dis. 110:56, 1974

20. Thorn, G. W., Adams, R. D., Braunwald, E., Isselbacher, K. J., Petersdorf, R, G.:Harrison's Principles of Internal Medicne, 8th ed. McGraw-Hill, Kogakusha, LTD, Tokyo, 1977

21. Barnett, T. B ., Herring, C. L. and Hill, C.: Lung abscess, Initial and late results of medical therapy, Arch. Int. Med. 127:217, 1971

22. King. D. S., and Lord, F. T.: Certain aspects of pulmonary abscess from analysis of 210 cases, Ann. Int. Med. 8:468, 1934

23. 金炳基, 吳尚伯, : 肺膿瘍의 外科的治療와 臨 床觀察, 結核哭 呼吸器疾患 19:11, 1965

24. Sabiston, D. C.: Textbook of surgery, 11th ed., W. B. Saunders Company, Philadelphia. 1977 
25. Mattox, K. L. and Guinn, G. A.: Emergency resection for massive hemoptysis, Ann. Thorac Surg. 17:377, 1974

26. Thoms, N. W., Willson, R. F., Puro, II. E. and Arbulu, A.: Life threatening hemoplisis in primary lung abscess, Ann. Thorac. Surg. 14: 347, 1972

27. Sweet, R. H.: Lung abscess, analysis of Masschusetts General Hospital case from 1933 through 1937, Surg. Gynec. \& Obst. 80:568, 1945 